\title{
Variations of structural protein sequences among geographical isolates of white spot syndrome virus
}

\author{
Toms C. Joseph $\cdot$ L. Anbu Rajan • Roswin James • \\ K. V. Lalitha $\cdot$ P. K. Surendran
}

Received: 24 August 2014/ Accepted: 5 November 2014/Published online: 18 November 2014

(C) The Author(s) 2014. This article is published with open access at Springerlink.com

\begin{abstract}
White spot syndrome virus (WSSV) is the causative agent of a disease that causes severe mortalities in cultured shrimp worldwide. The sequence of five structural genes of an Indian isolate of WSSV was compared with sequences from other WSSV isolates deposited in GenBank. Among the structural genes analyzed, the sequences of vp28 and vp19 had maximum divergence with nucleotide changes at ten different positions from twenty eight submissions for vp28 and six changes from seventeen submissions for vp19. The vp68, vp26, and vp281 genes were found to be highly conserved between isolates.
\end{abstract}

Keywords WSSV $\cdot$ Structural protein $\cdot$ vp28 $\cdot$ vp26 $\cdot$ vp19 $\cdot$ vp68 $\cdot$ vp281 $\cdot$ vp466

\section{Introduction}

White spot syndrome virus, a major pathogen of cultured shrimp first appeared in 1990s in Taiwan and China (Zhang et al. 1994; Wongteerasupaya et al. 1995; Nadala et al. 1998). Since then WSSV has spread rapidly to shrimp farming areas around the world causing heavy economic losses. White spot syndrome virus not only infects shrimp but also has a much wider host range which includes other invertebrate aquatic organisms such as crab, crayfish, and fresh water prawn, Macrobrachium sp. (Ramasamy 1995; Lo et al. 1996; Flegel 1997; Wang et al. 1998; Mohan et al. 1998).

WSSV is an enveloped ovoid virus with rod-shaped nucleocapsid with flat ends (Wang et al. 1995). WSSV is a major shrimp pathogen that is highly virulent in penaeid shrimp (Lo et al. 1996; Chen et al. 1997; Flegel 1997) and can result in of up to 90-100\% mortality within 3 to 7 days (Zhan et al. 1998). The virus belongs to the genus Whispovirus (Van Hulten et al. 2000; Tsai et al. 2000) under the family Nimiviridae. The complete genome sequence of WSSV has been determined for three different isolates with GenBank Accession numbers AF369029, AF440570, and AF332093 (Van Hulten et al. 2001, Yang et al. 2001, Lo and Kou 2001) for

T. C. Joseph · L. Anbu Rajan · R. James · K. V. Lalitha

Microbiology, Fermentation and Biotechnology Division, Central Institute of Fisheries Technology, Cochin 682 029, Kerala, India

L. Anbu Rajan ( $\square)$

Andaman and Nicobar Centre for Ocean Science and Technology, National Institute of Ocean Technology,

Dollygunj P.O., Port Blair 744 103, Andaman and Nicobar Islands, India

e-mail: anburajanl@yahoo.co.in

P. K. Surendran

Poothuvallil, Palluruthy, Cochin, India 
viruses isolated from Thailand, Taiwan, and China, respectively. The genome of WSSV is approximately $300 \mathrm{~kb}$ in length with 180 putative open reading frames. Most of the open reading frames of WSSV encode certain structural genes. Structural proteins of viruses are classified as envelope and non-envelope proteins. Envelope proteins play a vital role in virus entry assembly and release (Hsiao et al. 1999; Lin et al. 2000; Chiu and Chang 2002). Neutralization experiments of antibodies against six WSSV envelope proteins (vp28, vp26/ P22, vp466, vp281, vp68, and vp292) revealed that four envelope proteins (vp28, vp466, vp68, and vp281) play major roles in the initial steps of WSSV infection in shrimp (Wu et al. 2005). There is little genetic variation in the structural genes of WSSV from different geographical locations. (Lo et al. 1999; Moon et al. 2003; Satish et al. 2004; You et al. 2004). In this study, sequences of the genes encoding for six major structural proteins of WSSV from different geographical locations were compared with a WSSV isolate from south India.

\section{Materials and methods}

\section{Total DNA extraction}

Black tiger shrimp (Penaeus monodon) naturally infected with WSSV were obtained from a shrimp farm in Cochin, India. The samples were immediately transferred to sterile polythene bags and transported to the laboratory in ice. On arrival in the laboratory, the total DNA was extracted from pleopods as described previously (Moon et al. 2003).

PCR amplification of structural genes

The viral structural protein genes: vp28, vp26, vp19, vp68, vp281, and vp466 were amplified using six primer pairs (Table 1) designed based on the sequences of a Taiwanese isolate of WSSV (Yang et al. 2001). The primers were designed so as to include both the upstream and down stream sequences of the genes to be amplified. The PCR reaction was carried out in a final reaction volume of $50 \mu \mathrm{l}$ containing $0.5 \mu \mathrm{M}$ each of forward and reverse primer, $100 \mathrm{ng}$ of DNA, $200 \mu \mathrm{M}$ dNTP (MBI Fermentas, USA), $2.5 \mathrm{mM} \mathrm{MgSO}{ }_{4}, 1 \times P f u$ buffer, $1.25 \mathrm{U}$ of $P f u$ DNA polymerase (MBI Fermentas), and remaining autoclaved Millipore water. The amplification was performed in a PTC-150 Mini cycler (MJ Research, USA). The gene amplification conditions were as follows: primary denaturation at $94{ }^{\circ} \mathrm{C}$ for $5 \mathrm{~min}$, followed by 30 cycles of $94{ }^{\circ} \mathrm{C}$ for $30 \mathrm{~s}$, $55^{\circ} \mathrm{C}$ for $30 \mathrm{~s}$, and $72{ }^{\circ} \mathrm{C}$ for $2 \mathrm{~min}$, and final extension at $72{ }^{\circ} \mathrm{C}$ for $5 \mathrm{~min}$. The PCR amplified products were analyzed on $1.5 \%$ agarose gel along with DNA molecular weight marker and documented using a gel documentation system (Alpha Imager 1220, Alpha Innotech, USA).

\section{Cloning of PCR products in $\mathrm{pTZ57R/T}$}

An A-overhang was added to the PCR product for cloning into TA vector. The reaction was carried at $72{ }^{\circ} \mathrm{C}$ for $45 \mathrm{~min}$ in a reaction volume of $30 \mu \mathrm{l}$ containing $26 \mu \mathrm{M}$ dATP, $1 \times$ Taq buffer, 1.25 units of Taq DNA polymerase (MBI Fermentas), and the PCR product. The A-overhang added PCR product was purified using MinElute Gel purification kit (Qiagen, Germany). InsTA clone PCR cloning kit (MBI Fermentas) was used to clone the PCR product to pTZ57R/T vector. Ligation was set at $4{ }^{\circ} \mathrm{C}$ overnight in a $30 \mu \mathrm{l}$ reaction volume using $5 \mathrm{U}$ of T4 DNA ligase (MBI Fermentas). Competent E. coli JM109 cells were used as host system for transformation. The transformed cells were incubated at $37{ }^{\circ} \mathrm{C}$ overnight on LB agar plates containing $40 \mu \mathrm{l}$ of $0.1 \mathrm{M}$ IPTG and $4 \mu \mathrm{l}$ of $20 \mathrm{mg} / \mathrm{ml} \mathrm{X}$-gal in order to enhance blue white selection by $\alpha$-complementation. Plasmids were isolated from the overnight culture by alkaline lysis method (Sambrook et al. 1989).

The recombinant clones having the specific insert in the forward orientation was then sequenced from both directions to get a contiguous sequence in an automated sequencer (ABI prism, model 377, Version 3.0). The nucleotide sequences obtained and the deduced amino acid sequences were analyzed using bioinformatics tools. Sequences were compared with database using BLAST (http://www.ncbi.nlm.nih.gov/BLAST) blastn and blastp (Altschul et al. 1990). 
Table 1 Primers used for amplification of WSSV structural genes

\begin{tabular}{|c|c|c|c|}
\hline Sl. No. & Gene & Sequence $\left(5^{\prime}-3^{\prime}\right)$ & Product size (bp) \\
\hline \multirow[t]{2}{*}{1} & \multirow[t]{2}{*}{ vp28 } & F-5'TTCACGAGGTTGTCATCACC3' & \multirow[t]{2}{*}{799} \\
\hline & & R-5'TGGTATAAATTTCCTCAATTGTTTT3' & \\
\hline \multirow[t]{2}{*}{2} & \multirow{2}{*}{ vp26 } & F-5'TGGATCCAACCAACACGTAA3' & \multirow[t]{2}{*}{713} \\
\hline & & R-5'CTTGTATTTTTATTCAAACAAAACCTT3' & \\
\hline \multirow[t]{2}{*}{3} & \multirow[t]{2}{*}{ vp19 } & F-5'GGTGTCCTGACAAAAACCGTA3' & \multirow[t]{2}{*}{477} \\
\hline & & R-5'TTGTCCCTGATGTTGTGTTTTC3' & \\
\hline \multirow[t]{2}{*}{4} & \multirow[t]{2}{*}{ vp68 } & F-5'AACACTTCTGGGTGAAACCTA3' & \multirow[t]{2}{*}{323} \\
\hline & & R-5'TCGGACAAATAAAAGAATTGGAA3' & \\
\hline \multirow[t]{2}{*}{5} & \multirow[t]{2}{*}{ vp281 } & F-5'AGAAACCCAAGGAAGGGTTG3' & \multirow[t]{2}{*}{927} \\
\hline & & R-5'TTTGTTTGCAACACCCTTTT3' & \\
\hline \multirow[t]{2}{*}{6} & \multirow[t]{2}{*}{ vp466 } & F-5'TCAAGACCAGTACACGTAATTTGAT3' & \multirow[t]{2}{*}{1471} \\
\hline & & R-5' TGATGTCTGAGCCATTTTTATTATG3' & \\
\hline
\end{tabular}

\section{Results and discussion}

Six envelope protein genes of WSSV: vp28, vp26, vp19 vp68, vp281, and vp466 on PCR amplification and sequence analysis revealed genes of expected size 615, 615, 366, 207, 846, and $1401 \mathrm{bp}$, respectively. These sequences were submitted to the GenBank with the assigned accession numbers EF534254, EF534253, EU012447, EF534252, EF534251, and EF534255, respectively. The gene sequences were compared with reported nucleotide and amino acid sequences (Tables 2, 3, 4, 5, 6, 7). The nucleotide sequence of vp28 was compared with twenty eight GenBank sequences from various geographical locations (Table 2). Only one sequence reported from India (Accession No.DQ013883) had 100\% homology with the WSSV isolate reported in this study. There was an $\mathrm{A} \rightarrow \mathrm{G}$ nucleotide substitution at position 125 for all the other reported sequences, which translated into a substitution of aspartic acid for glycine. The nucleotide change at position 125 was present only in two WSSV isolates from India including the isolate reported in this paper indicating that this mutation is restricted to India. A Chinese isolate (Accession No.AY682926) and a Korean isolate (Accession No. AF380842) had a nucleotide substitution at position 234 and 444, respectively, from $\mathrm{T} \rightarrow \mathrm{C}$ both of which did not translate to change of amino acid. Two sequences from China (AF502435 and AY249434) had an additional mutation at nucleotide position 119 from $\mathrm{G} \rightarrow$ A which translated into an amino acid substitution from arginine to histidine. A Thailand isolate (Accession No. EF194079), a Chinese isolate (Accession No. DQ979320), and an Indian isolate (Accession No. AY422228) had three nucleotide substitutions including that at position 125. The Thailand isolate had nucleotide substitution at position 113 from $\mathrm{T} \rightarrow \mathrm{A}$ and at 434 from $\mathrm{T} \rightarrow \mathrm{C}$ which translated into change of amino acid from valine to glutamic acid and leucine to proline, respectively. The Chinese isolate had $\mathrm{T} \rightarrow \mathrm{C}$ nucleotide substitutions at positions 306 and 536 with change of amino acid from valine at both positions to proline and alanine, respectively. The Indian isolate had substitutions from $\mathrm{T} \rightarrow \mathrm{C}$ at positions 483 and 485 with change of amino acid from phenylalanine to serine in the first position, while the second position was conserved. There was nucleotide substitutions at ten different positions with the isolates studied, seven of which translated to a change of amino acid.

The nucleotide sequence of the gene encoding for envelope protein vp26 was compared with 16 reported sequences and it was revealed that there was $100 \%$ similarity with fourteen of the reported sequences (Table 3). The $\mathrm{G} \rightarrow \mathrm{A}$ nucleotide substitution at the nucleotide position 575 for the Chinese isolate (Accession No. AY220746) resulted in a change of amino acid from arginine to lysine, while a nucleotide change for the Vietnamese isolate (Accession No. AJ551446) at nucleotide position 345 from $\mathrm{T} \rightarrow \mathrm{C}$ was conserved and did not translate to change of amino acid. The vp26 gene was found to be highly conserved among isolates from different geographical locations with just two nucleotide variations from the sixteen isolates compared.

The vp19 sequence was compared with seventeen reported sequences, and it was found that there was $100 \%$ sequence similarity with four WSSV isolates reported from India (DQ681071), Vietnam (AY160771), 
Table 2 Nucleotide and amino acid substitution in vp28 gene

\begin{tabular}{|c|c|c|c|}
\hline Accession nos. & $\begin{array}{l}\text { Position of } \\
\text { mutation }\end{array}$ & $\begin{array}{l}\text { Base } \\
\text { substitution }\end{array}$ & $\begin{array}{l}\text { Change in } \\
\text { amino acid }\end{array}$ \\
\hline DQ013883 & Nil & Nil & Nil \\
\hline $\begin{array}{l}\text { DQ902658, DQ681069, DQ098011, AY324881, AF332093a, AF272979, AY249443, } \\
\text { AY249442, AY249441, AY249440, AF227911, AJ551447, DQ013882, DQ01388,, } \\
\text { DQ007315, AF369029 }, \text { AY168644, AF440570 , AF173993, AY873785 }\end{array}$ & 125 & $\mathrm{~A} \rightarrow \mathrm{G}$ & $\mathrm{D} \rightarrow \mathrm{G}$ \\
\hline \multirow[t]{2}{*}{ AF380842 } & 125 & $\mathrm{~A} \rightarrow \mathrm{G}$ & $\mathrm{D} \rightarrow \mathrm{G}$ \\
\hline & 444 & $\mathrm{~T} \rightarrow \mathrm{C}$ & Nil \\
\hline \multirow[t]{2}{*}{ AF502435, AY249434 } & 125 & $\mathrm{~A} \rightarrow \mathrm{G}$ & $\mathrm{D} \rightarrow \mathrm{G}$ \\
\hline & 119 & $\mathrm{G} \rightarrow \mathrm{A}$ & $\mathrm{R} \rightarrow \mathrm{H}$ \\
\hline \multirow[t]{2}{*}{ AY682926 } & 125 & $\mathrm{~A} \rightarrow \mathrm{G}$ & $\mathrm{D} \rightarrow \mathrm{G}$ \\
\hline & 234 & $\mathrm{~T} \rightarrow \mathrm{C}$ & Nil \\
\hline \multirow[t]{3}{*}{ EF194079 } & 125 & $\mathrm{~A} \rightarrow \mathrm{G}$ & $\mathrm{D} \rightarrow \mathrm{G}$ \\
\hline & 113 & $\mathrm{~T} \rightarrow \mathrm{A}$ & $\mathrm{V} \rightarrow \mathrm{E}$ \\
\hline & 434 & $\mathrm{~T} \rightarrow \mathrm{C}$ & $\mathrm{L} \rightarrow \mathrm{P}$ \\
\hline \multirow[t]{3}{*}{ DQ979320 } & 125 & $\mathrm{~A} \rightarrow \mathrm{G}$ & $\mathrm{D} \rightarrow \mathrm{G}$ \\
\hline & 306 & $\mathrm{~T} \rightarrow \mathrm{C}$ & $\mathrm{V} \rightarrow \mathrm{P}$ \\
\hline & 536 & $\mathrm{~T} \rightarrow \mathrm{C}$ & $\mathrm{V} \rightarrow \mathrm{A}$ \\
\hline \multirow[t]{3}{*}{ AY422228 } & 125 & $\mathrm{~A} \rightarrow \mathrm{G}$ & $\mathrm{D} \rightarrow \mathrm{G}$ \\
\hline & 483 & $\mathrm{~T} \rightarrow \mathrm{C}$ & $\mathrm{F} \rightarrow \mathrm{S}$ \\
\hline & 485 & $\mathrm{~T} \rightarrow \mathrm{C}$ & Nil \\
\hline
\end{tabular}

${ }^{\text {a }}$ Complete genome sequence of WSSV

Table 3 Changes in vp26 gene sequence in GenBank

\begin{tabular}{|c|c|c|c|}
\hline Accession nos. & $\begin{array}{l}\text { Position of } \\
\text { mutation }\end{array}$ & $\begin{array}{l}\text { Base } \\
\text { substitution }\end{array}$ & $\begin{array}{l}\text { Change in } \\
\text { amino acid }\end{array}$ \\
\hline $\begin{array}{l}\text { AF308164, AF332093 }{ }^{\mathrm{a}} \text {, AF272980, AY249439, AY249438, AY249437, } \\
\text { AY249436, AY249435, AY422230, AF380841, AF369029 a , AF440570, } \\
\text { AF173992, DQ681070 }\end{array}$ & Nil & Nil & Nil \\
\hline AY220746 & 575 & $\mathrm{G} \rightarrow \mathrm{A}$ & $\mathrm{R} \rightarrow \mathrm{K}$ \\
\hline AJ551446 & 345 & $\mathrm{~T} \rightarrow \mathrm{C}$ & Nil \\
\hline
\end{tabular}

${ }^{a}$ Complete genome sequence of WSSV

Table 4 Changes in vp19 gene sequence in GenBank

\begin{tabular}{llll}
\hline Accession nos. & $\begin{array}{l}\text { Position of } \\
\text { mutation }\end{array}$ & $\begin{array}{l}\text { Base } \\
\text { substitution }\end{array}$ & $\begin{array}{l}\text { Change in } \\
\text { amino acid }\end{array}$ \\
\hline DQ681071, AY160771, AF440570, AJ937860 & Nil & Nil & Nil \\
AY316119, AY873786 & 57 & $\mathrm{~T} \rightarrow \mathrm{C}$ & $\mathrm{Nil}$ \\
AF332093, AF402997 & 196 & $\mathrm{C} \rightarrow \mathrm{T}$ & $\mathrm{P} \rightarrow \mathrm{S}$ \\
AY249448, AY249447, Ay249446, AY248445, AY249444, AY220744, AF369029 & 218 & $\mathrm{~T} \rightarrow \mathrm{A}$ & $\mathrm{V} \rightarrow \mathrm{D}$ \\
AY422227 & 25 & $\mathrm{~T} \rightarrow \mathrm{C}$ & $\mathrm{S} \rightarrow \mathrm{P}$ \\
& 44 & $\mathrm{~T} \rightarrow \mathrm{C}$ & $\mathrm{V} \rightarrow \mathrm{A}$ \\
DQ902655 & 25 & $\mathrm{~T} \rightarrow \mathrm{C}$ & $\mathrm{S} \rightarrow \mathrm{P}$ \\
& 44 & $\mathrm{~T} \rightarrow \mathrm{C}$ & $\mathrm{V} \rightarrow \mathrm{A}$ \\
& 287 & $\mathrm{C} \rightarrow \mathrm{T}$ & $\mathrm{T} \rightarrow \mathrm{M}$ \\
\hline
\end{tabular}

${ }^{a}$ Complete genome sequence of WSSV 
Table 5 Changes in vp68 gene sequence in GenBank

\begin{tabular}{llll}
\hline Accession nos. & Position of mutation & Base substitution & Change in amino acid \\
\hline AF332093 $^{\mathrm{a}}, \mathrm{AF} 369029^{\mathrm{a}}, \mathrm{AF} 440570^{\mathrm{a}}, \mathrm{AF} 4114664$ & Nil & Nil & Nil \\
\hline
\end{tabular}

Table 6 Changes in vp281 gene sequence in GenBank

\begin{tabular}{llll}
\hline Accession nos. & Position of mutation & Base substitution & Change in amino acid \\
\hline AF332093, $^{\mathrm{a}}$ AF369029, ${ }^{\mathrm{a}}$ AF440570, AF411634 & 807 & $\mathrm{~A} \rightarrow \mathrm{T}$ & Nil \\
DQ979321 & 807 & $\mathrm{~A} \rightarrow \mathrm{T}$ & Nil \\
& 841 & $\mathrm{C} \rightarrow \mathrm{A}$ & $\mathrm{P} \rightarrow \mathrm{T}$ \\
AY517490 & 807 & $\mathrm{~A} \rightarrow \mathrm{T}$ & Nil \\
& 843 & $\mathrm{G} \rightarrow \mathrm{A}$ & Nil \\
\hline
\end{tabular}

Table 7 Changes in vp466 gene sequence in GenBank

\begin{tabular}{llll}
\hline Accession nos. & Position of mutation & Base substitution & Change in amino acid \\
\hline AF332093, AF440570, AF395545 & Nil & Nil & Nil \\
AF369029 & 1212 & A $\rightarrow$ T & K $\rightarrow$ N \\
\hline
\end{tabular}

${ }^{a}$ Complete genome sequence of WSSV

Taiwan (AF440570), and Mexico (AJ937860) (Table 4). Point mutations: $\mathrm{T} \rightarrow \mathrm{C}, \mathrm{T} \rightarrow \mathrm{A}$ and $\mathrm{C} \rightarrow \mathrm{T}$ were found at six different nucleotide positions with 13 reported sequences. To ascertain whether the variation at nucleotide level resulted in change in at amino acid level, the protein sequences of vp19 gene were also compared. The $\mathrm{T} \rightarrow \mathrm{C}$ point mutation at position 57 (Accession No. AY316119 and AY873786) did not result in change in amino acid while a $\mathrm{C} \rightarrow \mathrm{T}$ mutation at position 196 (Accession No. AF332093 and AF402997) resulted in change amino acid from proline to serine. A $\mathrm{T} \rightarrow \mathrm{A}$ mutation at position 218 (Accession No. AY249444 to AY249448 and AF369029) had a change in amino acid from valine to aspartic acid. Two reported sequences from India, (Accession Nos. AY422227 and DQ902655), gave a T $\rightarrow$ C mutation at nucleotide positions 25 and 44 that translated into change of amino acids; serine to proline and valine to alanine, respectively. The WSSV isolate with Accession No. DQ902655 had a C $\rightarrow$ T extra substitution at position 287 other than at nucleotide positions 25 and 44 that translated into methionine, a change in the amino acid from threonine.

The vp68 sequence was $100 \%$ similar with the four reported sequences (Table 5). Comparison of vp281 sequence with six published sequences revealed $\mathrm{A} \rightarrow \mathrm{T}, \mathrm{C} \rightarrow \mathrm{A}$, and $\mathrm{G} \rightarrow \mathrm{A}$ mutations at three different nucleotide positions (Table 6). The $\mathrm{A} \rightarrow \mathrm{T}$ mutation at nucleotide position 807 present in all the reported sequences did not translate into change of amino acid. While the $\mathrm{C} \rightarrow \mathrm{T}$ mutation at position 841 (Accession No. DQ979321) translated into change in amino acid from proline to threonine. The $G \rightarrow A$ mutation at position 843 (Accession No. AY517490) did not translate into change of amino acid. Three reported nucleotide sequence of vp466 had $100 \%$ homology with the sequence reported in the present study (Table 7). There was an $\mathrm{A} \rightarrow \mathrm{T}$ nucleotide substitution at position 1212 for a Thailand isolate, which translated into a substitution of lysine to arginine.

In the present study, the sequences of six envelope proteins were compared with reported sequences of WSSV isolates. A common ancestor for the virus isolate could not be designated as there was variation in sequence with one envelope protein or other. The vp26 gene of the Taiwanese, Thailand, Chinese, and Korean isolates were identical at both nucleotide and amino acid levels, while the vp28 gene was $99 \%$ identical at nucleotide level and $100 \%$ identical at amino acid level (Moon et al. 2003). Sequence of five WSSV structural proteins (vp15, 19, 24, 26, and 28) from 5 different geographical WSSV isolates when compared with four WSSV isolates reported showed that the sequence of each gene were identical among the 9 isolates with the exception of vp28 gene of a Korean isolate with 1 base change from that of other WSSV isolates. However, this base change did not result in change of amino acid sequence (You et al. 2004). The extent of 
sequence variation among the isolates suggests that newer strains of WSSV are evolving that may have variations in their virulence potential. Chang et al. 2002 attributed the point mutations in the envelope proteins to the non-infectious nature of the virus isolate.

Highly conserved DNA and amino acid sequence of the structural proteins of WSSV provide the basis for the development of sensitive nucleic acid and antibody-based detection methodology for WSSV (You et al. 2004). Many PCR and protein-based diagnostic tests target the envelop proteins. However, variations in sequence of envelop proteins may result in false negative results. Recombinant vp28 and vp19 were found to have potential for use as injected vaccine or oral vaccine (Witteveldt et al. 2004). The variations at nucleotide and amino acid in the structural genes can result in difference in the protection offered by these proteins when used as vaccines. Hence further studies need to be done to ascertain the efficacy of these proteins in providing protection against the virus.

Author contribution Research concept and the experiments were performed by TCJ, LAR and RJ. KVL and PKS analyzed the data and reviewed the manuscript. All authors approved the final manuscript.

Acknowledgments Authors are grateful to the Director, Central Institute of Fisheries Technology (CIFT), Cochin for providing the necessary facilities to carry out this research work and Indian Council for Agricultural Research, New Delhi, India for financial assistance.

Conflict of interest The authors declare that they have no conflict of interest in the publication.

Open Access This article is distributed under the terms of the Creative Commons Attribution License which permits any use, distribution, and reproduction in any medium, provided the original author(s) and the source are credited.

\section{References}

Altschul SF, Gish W, Miller W, Myersand EW, Lipman DJ (1990) Basic local alignment search tool. J Mol Biol 215:403-410

Chang YS, Lo CF, Peng SE, Liu KF, Wang CH, Kou GH (2002) White spot syndrome virus (WSSV) PCR-positive Artemia cysts yield PCR-negative nauplii that fail to transmit WSSV when fed to shrimp post larvae. Dis Aquat Org 49:1-10

Chen XF, Chen C, Wu DH, Huai H, Chi XC (1997) A new baculovirus of cultured shrimp. Sci China Ser C 40:630-635

Chiu WL, Chang W (2002) Vaccinia virus J1R protein: a viral membrane protein that is essential for virion morphogenesis. J Virol 756:9575-9587

Flegel TW (1997) Major viral diseases of black tiger prawn (Penaeus monodon) in Thailand. World J Microbiol Biotechnol 13:433-442

Hsiao JC, Chung CS, Chang W (1999) Vaccinia virus envelope D8L protein binds to cell surface chondroitin sulfate and mediates the adsorption of intracellular mature virions to cell. J Virol 73:8750-8761

Huang CH, Zhang XB, Lin QS, Xu X, Hu ZH, Hew CL (2002) Proteomic analysis of shrimp white spot syndrome viral proteins and characterization of a novel envelope protein vp466. Mol Cell Proteomics 1:223-231

Lin CL, Chung CS, Heine HG, Chang W (2000) Vaccinia virus envelope protein H3L protein binds to cell surface heparin sulfate and is important for intracellular mature virion morphogenesis and virus infection in vitro and in vivo. J Virol 74:3353-3365

Lo CF, Kou GH (2001) Shrimp white spot syndrome virus, complete genome. GenBank, gi: 19481591, AF440570.1, 26-OCT2001

Lo CF, Ho CH, Peng SE, Chen CH, Hsu HC, Chiu YL, Chang CF, Liu KF, Su MS, Wang CH, Kou GH (1996) Whitespot syndrome baculovirus (WSBV) detected in cultured and captured shrimp arthropods. Dis Aquat Org 27:215-226

Lo CF, Hsu HC, Tsai MF, Ho CH, Peng SE, Kou GH, Lightner DV (1999) Specific genomic DNA fragment analysis of different geographical clinical samples of shrimp white spot syndrome virus. Dis Aquat Org 35:175-185

Mohan CV, Shanker KM, Kulkarni S, Sudha PM (1998) Histopathology of cultured shrimp showing gross signs of yellow head syndrome and white spot syndrome during 1994 Indian epizootics. Dis Aquat Org 34:9-12

Moon CH, Do JW, Cha SJ, Yoon WJ, Kim SB, Ko MS, Park MA, Kim JW, Sohn SK, Lee JH, Park JW (2003) Highly conserved sequences of three major virion proteins of Korean isolates of white spot syndrome virus (WSSV). Dis Aquat Org 53:11-13

Nadala ECB, Tapay LM, Loh PC (1998) Characterization of a non-occluded baculovirus-like agent pathogenic to penaeid shrimp. Dis Aquat Org 33:221-229

Ramasamy P (1995) Diseases of shrimp in aquaculture systems; diagnosis and therapeutic measures. Vanitha Publications (Eds.), Madras, pp 1-99

Sambrook J, Fritsch EF, Maniatis T (1989) Molecular cloning: a laboratory manual, 2nd edn. Cold Spring Harbor Laboratory Press, Cold Spring Harbor

Satish S, Musthaq S, Sahul Hameed AS, Narayanan RB (2004) Production of recombinant structural proteins from the Indian WSSV isolate. Aquaculture 242:69-80

Tsai MF, Yu HT, Tzeng HF, Leu JH, Chou CM, Huang CJ, Wang CH, Lin JY, Kou GH, Lo CF (2000) Identification and characterization of a shrimp white spot syndrome virus (WSSV) gene that encodes a novel chimeric polypeptide of cellulartype thymidine kinase and thymidylate kinase. Virology 277:100-110 
Tsai JM, Wang HC, Leu JH, Hsiao HH, Wang AHJ, Kou GH, Lo CF (2004) Genomic and proteomic analysis of thirty-nine structural proteins of shrimp white spot syndrome virus. J Virol 78:11360-11370

Van Hulten MC, Tsai MF, Schipper CA, Lo CF, Kou GH, Valk JM (2000) Anaysis of genomic segment of white spot syndrome virus of shrimp containing ribonucleotide reductase genes and repeat regions. J Gen Virol 81:307-316

Van Hulten MC, Witteveldt J, Peters S, Kloosterboer N, Tarchini R, Fiers M, Sandbrink H, Lankhorst RK, Valk JM (2001) The white spot syndrome virus DNA genome sequence. Virology 286:7-22

Wang CH, Lo CF, Leu JH (1995) Purification and genomic analysis of baculovirus associated with white spot syndrome (WSBV) of Penaeus monodon. Dis Aquat Org 23:239-242

Wang YC, Lo CF, Chang PS, Kou GH (1998) Experimental infection of white baculovirus in some cultured and wild decapods in Taiwan. Aquaculture 164:221-231

Witteveldt J, Cifuentes CC, Vlak JM, Van Hulten MCW (2004) Protection of Penaeus monodon against white spot syndrome virus by oral vaccination. J Virol 78:2057-2061

Wongteerasupaya C, Vickers JE, Sriurairatana S, Nash GL, Akarajamorn A, Boonsaeng V, Panyim S, Tassanakajon A, Withyachumnarnkul B, Flegel TW (1995) A non-occluded, systemic baculovirus that occurs in cells of ectodermal and mesodermal origin and causes high mortality in black tiger prawn Penaeus monodon. Dis Aquat Org 21:69-77

Wu W, Wang L, Zhang X (2005) Identification of white spot syndrome virus (WSSV) envelope proteins involved in shrimp infection. Virology 332:578-583

Yang F, He J, Lin XH, Li Q, Pan D, Zhang X, Xu X (2001) Complete genome sequence of the shrimp white spot bacilliform virus. J Virol 75:11811-11820

You Z, Nadala ECB, Yang J, Loh PC (2004) Conservation of the DNA sequences encoding the major structural viral proteins of WSSV. Dis Aquat Org 61:159-163

Zhan WB, Wang YH, Fryer JL, Yu KK, Fukuda H, Meng QX (1998) White spot syndrome virus infection of cultured shrimp in China. J Aquat Anim Health 10:405-410

Zhang L, Zhang J, Chen D, Xia OL (1994) Assembly of rod shaped virus of Penaeus orientalis kishinoye in vivo. J Chin Electron Microsc Soc 13:354-363 